\title{
New Literature
}




\title{
New literature (A selection from Nordicom's database NCOM)
}

\author{
Denmark \\ Documentalist: Mogens Vestergaard Kjeldsen
}

\section{Taming Time, Timing Death \\ Social Technologies and Ritual}

Dorthe Refslund Christensen \& Rane Willerslev (eds.) Surrey, UK, Ashgate, 2013. 288 s. ISBN 9781409450689 .

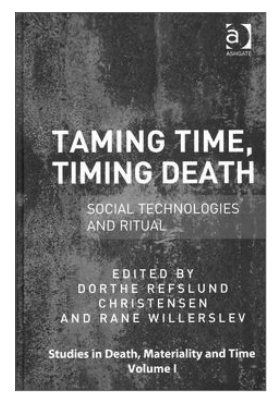

Departing from a persisting current in Western thought, which conceives of time in the abstract, and often reflects upon death as occupying a space at life's margins, this book begins from position that it is in fact through the material and perishable world that we experience time. As such, it is with death and our encounters with it, that form the basis of human conceptions of time. Presenting rich, interdisciplinary empirical studies of death rituals and practices across the globe, from the US and Europe, Asia, The Middle East, Australasia and Africa, Taming Time, Timing Death explores the manner in which social technologies and rituals have been and are implemented to avoid, delay or embrace death, or communicate with the dead, thus informing and manifesting humans' understanding of time. It will therefore be of interest to scholars and students of anthropology, philosophy, sociology and social theory, human geography and religion.

\section{Digital Media Ethics}

2. udgave

Charles Ess, Polity Press, 2013. 280 s. ISBN 9780745656052 , ISBN (elektronisk) 9780745656069.

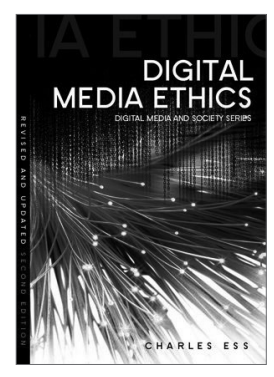

The original edition of this accessible and interdisciplinary textbook was one of the first to consider the ethical issues of digital media from a global perspective, introducing ethical theories from multiple cultures. This second edition has been thoroughly updated to cover current research and scholarship, and recent developments and technological changes. It also benefits from extensively updated case-studies and pedagogical material, including examples of "watershed" events such as privacy policy developments on Facebook and Google+ in relation to ongoing changes in privacy law in the US, the EU, and Asia. New for the second edition is a section on "citizen journalism" and its implications for traditional journalistic ethics. With a significantly updated section on the "ethical toolkit," this book also introduces students to prevailing ethical theories and illustrates how they are applied to central issues such as privacy, copyright, pornography and violence, and the ethics of crosscultural communication online.

\section{Researching Virtual Worlds}

Methodologies for Studying Emergent Practices

Ursula Plesner \& Louise Jane Phillips, New York, Routledge, 2013. 186 s. ISBN 9780415624442, ISBN (elektronisk) 9780203104644.

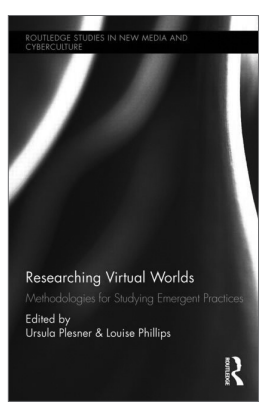

This volume presents a wide range of methodological strategies that are designed to take into account the complex, emergent, and continually shifting character of virtual worlds. It interrogates how virtual worlds emerge as objects of study through the development and application of various methodological strategies. Virtual worlds are not considered objects that exist as entities with fixed attributes independent of our continuous engagement with them and interpretation of them. Instead, they are conceived of as complex ensembles of technology, humans, symbols, discourses, and economic structures, ensembles that emerge in ongoing practices and specific situations. A broad spectrum of perspectives and methodologies is presented: Actor-Network-Theory and post-ActorNetwork-Theory, performativity theory, ethnography, discourse analysis, Sense-Making Methodology, visual ethnography, multi-sited ethnography, and Social Network Analysis. 


\section{Other new literature}

\section{Ph.d.-dissertations}

Ebsen, T. (2013). Material Screen: Intersections of media, art and architecture. Aarhus: Aarhus Universitet, Institut for Æstetik og Kommunikation.

Kammer, A. S. (2013). News on the Web: Instantaneity, multimodality, interactivity, and hypertextuality on Danish news websites. Københavns Universitet, Det Humanistiske Fakultet.

Korsgaard, M. B. (2013). Music Video Today: Audiovisual Remediation in Postmillennial Music Video. Aarhus: Aarhus Universitet, Institut for Æstetik og Kommunikation.

\section{Articles}

Bødker, M., \& Browning, D. (2013). Inspiring Design: Social Media from the Beach. I Munar, A. M., Gyimóthy, S., \& Cai, L. (red.), Tourism Social Media. Kapitel 7. (s. 107-131). Bingley: Emerald Group Publishing Limited.

Brügger, N. (2013). Historical Network Analysis of the Web. Social Science Computer Review, 31(3), 306-321

Bruun, H. (2013). Political Satire in Danish Television: Reinventing a Tradition. I Baym, G., \& Jones, J. P. (red.), News Parody and Political Satire Across the Globe. (1 udg.) Kapitel 13. (s. 157-169). New York: Routledge/Taylor and Francis Group.

Ess, C. (2013). Global Media Ethics?: Issues, Requirements, Challenges, Resolutions. I Ward, S. (red.), Global Media Ethic. Kapitel 13. (s. 253-272). Wiley-Blackwell.

Have, I., \& Pedersen, B. S. (2013). Sonic mediatization of the book: affordances of the audiobook. MedieKultur, 29(54), 123-140.

Helles, R. (2013). The big head and the long tail: An illustration of explanatory strategies for big data Internet studies. First Monday, 18(10).

Holm, A. B., Günzel, F., \& Ulhøi, J. P. (2013). Openness in innovation and business models: lessons from the newspaper industry. International Journal of Technology Management, 61(3/4), 324-348

Jensen, K. (2013). How to do things with data: Metadata, meta-media, and meta-communication. First Monday, 18(10).
Klitgaard, M. B., \& Elmelund-Præstekær, C. (2013). Partisan Effects on Welfare State Retrenchment: Empirical Evidence from a Measurement of Government Intentions. Social Policy and Administration, 47(1), 50-71.

Lund, A. B., \& Blach-Ørsten, M. (2013). Media and Politics. I Brincker, B. (red.), Introduction to Political Sociology. Kapitel 8. (s. 153-170). København: Hans Reitzel.

Olsson, T., Viscovi, D., Tomanic Trivundza, I. (red.), Carpentier, N. (red.), Nieminen, H. (red.), PruulmannVengerfeldt, P. (red.), Kilborn, R. (red.), \& Sundin, E. (red.) (2013). Impediments to Participation: UGC and Professional Culture. I Past, Future and Change: Contemporary Analysis of Evolving Media Scapes. (s. 283-295).

Plesner, U. (2013). Virtual Worlds as Emerging Cyberhybrids: Accounting for the Travel Between Research Sites with Actor-Network-Theory. I Plesner, U., \& Phillips, L. (red.), Researching Virtual Worlds. Kapitel 2. (s. 16-33). New York: Routledge.

Stage, C. (2013). The Online Crowd: A Contradiction in Terms?. Distinktion, 14(2), 211-226.

Tunby Gulbrandsen, I., \& Nørholm Just, S. (2013). Collaboratively Constructed Contradictory Accounts: Online Organizational Narratives . Media, Culture and Society, 35(5), 565-585.

Uldam, J. (2013). Activism and the Online Mediation Opportunity Structure: Attempts to Impact Global Climate Change Policies?. Journal of Internet policy, 5(1), 56-75.

Uldam, J., \& Askanius, T. (2013). Calling for Confrontational Action in Online Social Media: Video Activism as Auto-communication. I Cammaerts, B., Mattoni, A., \& McCurdy, P. (red.), Mediation and Protest Movements. Kapitel 8. (s. 159-178). Bristol: Intellect Ltd.

Ulhøi, J. P., \& da Mota Pedrosa, A. (red.) (2013). Editorial: Special issue. International Journal of Technology Management, 61(3/4), 199-204. 


\section{Finland \\ Documentalist Eija Poteri}

\section{Illusions in Motion \\ Media Archeology of the Moving Panorama and Related Spectacles}

Erkki Huhtamo, Cambridge (Mass.): MIT Press, 2013. 438 p., ISBN 978-0-262-01851-7.

The moving panorama was a long painting that unscrolled behind a "window" by means of a mechanical

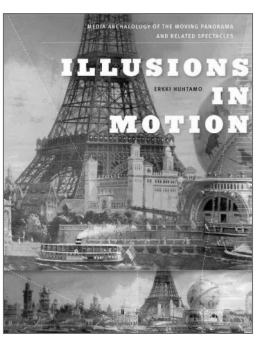

cranking system, accompanied by a lecture, music, and sometimes sound and light effects. Showmen exhibited such panoramas in venues that ranged from opera houses to church halls, creating a market for mediated realities in both city and country.

Contents: The Formation of a Panoramaniac-Introduction: Moving Panorama -a Missing Medium -The Incubation Era: Antecedents and Anticipations -Large as Life, and Moving: The Peristrephic Panorama -Rolling Across the Stage: The Moving Panorama and the Theatre -Transformed By The Light: The Diorama and the "dioramas" -The Panoramania, or The Mid-Century Moving Panorama Craze -Panoramania in Practice: Albert Smith and his Moving Panoramas -The Moving Panorama Performance: an Excavation -Intermedial Tug of War, or Panoramas and Magic Lanterns -Sensory Bombardment: a Medium's Final Fanfares -The Discursive Transfiguration of the Moving Panorama -Conclusion: From Panoramas to Media Culture.

\section{Media and Digital Literacies in Secondary School}

Reijo Kupiainen, New York: Peter Lang, 2013, 160 p., (New literacies and digital epistemologies, 59). ISBN 978-1-4331-1841-8, ISBN 978-1-4331-1840-1.

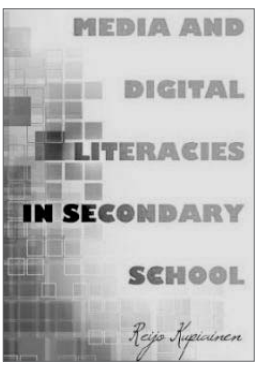

The book examines young people's media practices and media literacies in school spaces where these practices mix in the school environment and learning in different ways. Young people bring their own media and literacy practices to the school as an important part of an identity, taste, and social life. These practices are changing school's media ecology, making school's physical boundaries more permeable, creating new, unofficial spaces in them, and transgressing the boundaries of private and public. The book highlights youth's media production practices, from photography and video making to fan fiction writ- ing and online role-playing, which have different relations to the school, and shows how these practices make a dialog between informal and formal learning and that teachers have an important part in collaborative relationships with pupils when teachers encourage and motivate pupils and help them to understand media phenomena.

\section{Co-created Mobile Narratives}

Marjo Mäenppää, Turku: University of Turku, 2013. 203 p. ISBN 978-951-29-5356-1. Doctoral dissertation.

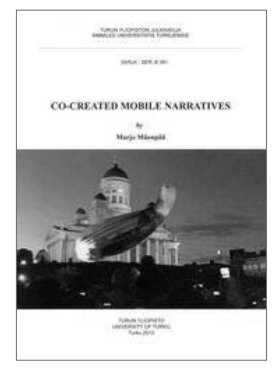

The study seeks answers to the questions of how people tell "mobile" stories using their phones and how a community creates narrative through mobile phones, using video. Questions are based on claims that people today are telling stories through social media and, also, visually - through images and videos. One of the main hypotheses is that mobile and collective story production is a creative process where the end result is unpredictable. In this study the author investigates how the narrative is structured, what the co-creation process is and do the co-created videos fullfill the design principles of narratives. How do we define the "author" and narrator in co-created narratives?

\section{The Bilingual Screen \\ Ethnolinguistic Identity and Television Viewing among Three Language Minorities}

Laszlo Vincze, Helsingfors: Svenska social- och kommunalhögskolan vid Helsingfors universitet, 2013. ISBN 978-952-10-5238-5. Doctoral dissertation.

The purpose of the present study was to examine the relationship between ethnolinguistic identity and television viewing among minority language speakers.

Inspired by the model proposed by Abrams, Eveland and Giles (2003), and Reid, Giles and Abrams (2004), the study integrated ethnolinguistic identity theory (Giles and Johnson, 1981, 1987), uses and gratifications approach (Katz, Blumler and Gurevitch, 1974; Katz, Gurevitch and Haas, 1973) and cultivation theory (Gerbner and Gross, 1976). More precisely, a novel model was proposed, that consisted of two parts reflecting the idea of ethnolinguistic identity gratifications and ethnolinguistic cultivation. From the point of view of ethnolinguistic identity gratifications, it was examined how ethnolinguistic identity influences media needs and media use; whereas, from the perspective of ethnolinguistic cultivation, the research inspected the relationship between television viewing, the perception about ethnolinguistic social context (like perceived vitality, 
permeability and status stability) and ethnolinguistic identity management strategies (mobility, creativity and competition).

The hypotheses were tested empirically among young media users in the German minority in South-
Tyrol, Italy; the Hungarian minority in Transylvania, Romania ; and the Swedish minority in Southern Finland. The data was analysed with variance analyses, correlational analyses, OLS-regressions and multiple mediations.

\section{Other new literature}

Kivimäki, Sanna (ed.). Media and communication research in Finnish universities: evaluation report. Helsinki, Academy of Finland, 2013, 98 p., (Publications of the Academy of Finland, 1/13). ISBN 978-951-715-846-6.

\section{Articles}

Ahva, L. (2013). Public journalism and professional reflexivity. Journalism:Theory, Practice \& Criticism, 14(6), 790-806.

Aitamurto, T. (2013). Balancing between open and closed: Co-creation in magazine journalism. Digital Journalism, 1(2), 229-251

Ala-Fossi, M. (2013). A evolução do rádio e o impacto na/da audiência. Significação - Revista de Cultura Audiovisual , 40(39), 88-112.

Aula, P. \& Mantere, S. (2013). Making and breaking sense. An inquiry into reputation change. Journal of Organizational Change Management 26(2), 340-352.

Hellman, H., \& Keinonen, H. (2013). Semi-commercial or semi-public service?: legitimacy and regulation of commercial television in Finland . Comunicazioni Sociali, (1), 44-57.

Hujanen, J. (2013) At the crossroads of participation and objectivity. Reinventing citizen engagement in the SBS newsroom. New Media \& Society 15(6), 947-962.

Kantola, A. (2013). From gardeners to revolutionaries. The rise of the liquid ethos in political journalism. Journalism: Theory, Practice \& Criticism 14(5), 606-626.

Karppinen, K. (2013). Uses of democratic theory in media and communication studies. Observatorio (OBS*) Journal, 7(3).

Kivikuru, U. (2013). When the history turns stronger than the rhetoric: The journalistic culture drives over democracy ideals in Namibia and Tanzania. In. Olorunnisola, A. \& Douai, A. (Eds.) New media influence on social and political change in Africa (pp. 118-146). Hershey, PA: IGI Global. ISBN 978-1-4666-4197-6.

Kivikuru, U. (2013). Upstairs downstairs: Communication contradictions around two African refugee camps. Journal of African Media Studies 5(1), 35-52.
Kolamo, S. \& Vuolteenaho, J. (2013). The interplay of mediascapes and cityscapes in a sports mega-event. The power dynamics of place branding in the 2010 FIFA World Cup in South Africa. International Communication Gazette 75(5-6), 502-520.

Koskela, M. (2013) Same, same, but different. Intertextual and interdiscursive features of communication strategy texts. Discourse \& Communication 7(4), 1-19.

Lahti, M. \& Valo, M. (2013). The Development of intercultural relationships at work: Polish migrant workers in Finland. Journal of Intercultural Communication 13(31).

Landgrén, L-F. (2013). Hitlers andra revolution i Tyskland sommaren 1934 i svensk och finländsk press. Historiks tidskrift för Finland, 98(1), 33-63.

Lassila-Merisalo, M. (2012). Veikko Ennala: taboobreaker in mid-20th-century Finland. In Keeble, R., \& Tulloch, J. (Eds.), Global literary journalism. (pp. 89-102). New York: Peter Lang. (Mass communication and journalism, Vol. 10).

Lowe, G. F., \& Edelvold Berg, C. (2013). The funding of public service media: A matter of value and values. International Journal on Media Management (JMM), 15(2), 77-97.

Luoma-aho, V., Leppänen, M., \& Uskali, T. (2013). Errand boy or entrepreneur?: Journalists' expectations of their future roles in Finland. Central European Journal of Communication, 6(2).

Luoma-aho, V., Tirkkonen, P. \& Vos, M. (2013). Monitoring the issue arenas of the swine-flu discussion. Journal of Communication Management 17(3), 239-251.

Meriläinen N. \& Vos, M. (2013). Framing issues in the public debate. The case of human rights. Corporate Communications. An International Journal 16(4), 292-310.

Niemelä, K., \& Christensen, H. R. (2013). Religion in the newspapers in the Nordic countries 1988-2008. Nordic Journal of Religion and Society, (1), 5-24.

Nikunen, K., \& Horsti, K. (2013). The ethics of hospitality in changing journalism: A response to the rise of the anti-immigrant movement in Finnish media publicity. European Journal of Cultural Studies, 16(4), 489-504. 
Nordenstreng, K. (2013). How the New World Order and imperialism challenge media studies. triple $C$, 11(2), 348-358.

Ojala, M. (2013). Mediating global imaginary: Obama's "address to the muslim world" in the Western European press. Journalism Studies 12(5), 673-688.

Pasti, S., \& Nordenstreng, K. (2012). Paradoxes of journalistic profession: Case of Russia in the context of the BRICS countries. World of Media: Yearbook of Russian Media and Journalism Studies, 2012, 243-268.

Puustinen, L., \& Seppänen, J. (2013). The image of trust: readers' views on the trustworthiness of news photographs. CM Communication Management Quarterly, 8(26), 11-32.

Sjö, S., \& Daníelsson, Á. S. (2013). Detraditionaliazation, diversity and mediatization: explorations of religion in Nordic films. Nordic Journal of Religion and Society, (1), 45-62.

Sumiala, J., \& Tikka, M. (2013). Broadcast yourself global news: A netnography of the "Flotilla" news on YouTube. Communication, Culture \& Critique, 6(2), 318-335.

Saarenmaa, L. (2013). The Cosmopolitan imagination in the Cold War context: Finnish fashion models and national fantasies of international success. Fashion Theory: The Journal of Dress, Body, Culture, 17(3), 321-340.
Tenscher, J., \& Mykkänen, J. (2013). Transformations in second-order campaigning: A German-Finnish comparison of campaign professionalism in the 2004 and 2009 European parliamentary elections. Central European Journal of Communication, 6(2).

Tolvanen, K., Olkkonen, L. \& Luoma-aho, V. (2013). The Legitimacy of the media industry: what do advertisers expect? Journal of Media Business Studies 10(2), 17-27.

Törrönen, J., \& Juslin, I. (2013). From genius of the home to party princess: Drinking in Finnish women's magazine advertisements from the 1960s to the 2000s. Feminist media studies, 13(3), 463-489.

Vincze, L. \& Moring, T. (2013). Towards ethnolinguistic identity gratifications. In. Gruffydd Jones, E. H. \& Uribe-Jongbloed, E. (Eds.). Social Media and Minority Languages Convergence and the Creative Industries (pp. 47-57). Bristol: Multilingual Matters. ISBN 978-1-84769-904-9.

Wahl-Jorgensen, K. \& Pantti, M. (2013). Ethics of global disaster reporting: Journalistic witnessing and objectivity. In: Ward, S. (Ed.) Global media ethics: Problems and perspectives. Wiley-Blackwell. ISBN 9781405183925 . 


\section{Norway \\ Documentalist: Ragnhild Mølster}

\author{
Children in the Online World \\ Risk, Regulation, Rights \\ Elisabeth Staksrud, Surrey, London: Ashgate Publis- \\ hing Group, 2013. 252 s. ISBN 978-1-4094-2550-2.
}

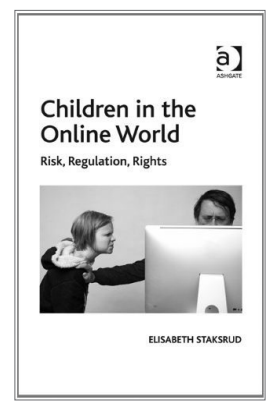

What is online risk? How can we best protect children from it? Who should be responsible for this protection? Is all protection good? Can Internet users trust the industry? These and other fundamental questions are discussed in this book. Beginning with the premise that the political and democratic processes in a society are affected by the way in which that society defines and perceives risks, It offers insights into the contemporary regulation of online risk for children (including teens), examining the questions of whether such regulation is legitimate and whether it does in fact result in the sacrifice of certain fundamental human rights. The book draws on representative studies with European children concerning their actual online risk experiences as well as an extensive review of regulatory rationales in the European Union, to contend that the institutions of the western European welfare states charged with protecting children have changed fundamentally, at the cost of the level of security that they provide. In consequence, children at once have more rights with regard to their personal decision making as digital consumers, yet fewer democratic rights to participation and protection as 'digital citizens'. Contents: Introduction; Individualization; Part I Risk!: Conceptualizing online risk; What is online risk?; Making risky decisions. Part II Regulation!: Regulation as legitimate protection; From authority to advisory; The NGO - friend or foe?; Who coaches the watchmen?. Part III Rights?: Which rights?; Citizen or consumer?; 'Child pornography is great!'; Good luck!

\section{Moving-image News Production in Two Newsrooms}

A News Ethnography of Discourses of Professionalism, Technology, and Journalistic Practices at TV2 Newschannel and VG Nett/VGTV, 2007-2009

Maria Konow Lund, PhD-avhandling, Oslo: Department of Media and Communication, Faculty of Humanities, University of Oslo, 2013. $351 \mathrm{~s}$.

This dissertation investigates the tension and interaction between two alternative discourses of professionalism, occupational and organizational, in terms of the use of technology and other routines and expectations related to journalism with moving images. This form of tension arises not from conflict as such but from competing or colliding priorities concerning both the product of and the practice in the digital-era newsroom. Journalists and managers must do more with less using technology that is often unfamiliar and always accelerating the tasks with which it assists. At the heart of the thesis, then, is the question of how media professionals cope with the impact of both time and space constraints and demands upon their work. The study is the result of field observation, field interviews, document analysis, and semistructured qualitative interviews with 125 informants. Konow Lund undertook her field observation at three different locations: TV2's newsroom in Oslo, TV2's newsroom in Bergen, and VG Nett's offices in Oslo during different periods in 2007, 2008 and 2009. The study is relatively unique in having deliberately compared the practices of journalism in television and online (hence the collective rubric 'journalism with moving images').

Changes that have arisen in the digital era have affected platforms old and new in profound ways and have instigated a shared practice that now operates in tandem with the traditional practices that have long distinguished, say, newspaper from television or television from Internet journalism. The research indicates that newsrooms undergoing this level of transformation, particularly those dependent upon 'heavy technology' such as video, have developed coping mechanisms that create ripple effects throughout the professionalism of both journalists (occupational) and managers (organizational). No one in the newsroom can any longer afford to be reactive - that is, to wait around for something to happen, then cover it. Journalists and managers must both anticipate and encourage activity even prior to events, for example by engaging the audience to watch for (and even produce) potential stories, then share them with the newsroom (and each other) via social media platforms and distribution channels. Production in an Internet newsroom (and, to a lesser extent, in a 24/7 television newsroom) is now 'active-reactive', thanks to these anticipatory efforts, and journalism has adapted to these new prerogatives and timeframes. Ultimately, we are witnessing the beginning of a new media economy, within which journalists act as well as react and synthesize as much as create, and this economy is strongly influencing the way journalists think about journalism. That negotiation process is the general quarry of the present thesis.

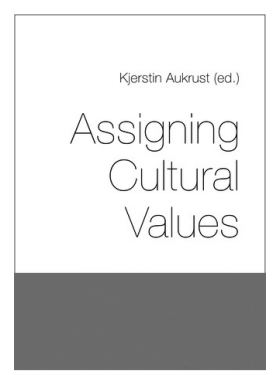

\section{Assigning Cultural Values}

Kjerstin Aukrust, Frankfurt am Main: Peter Lang, 2013. 298 s. ISBN 978-3-631-632987 , ISBN (elektronisk) 978-3653-02928-4 .

Assigning Cultural Values is a collection of thirteen essays focusing on the analysis of cultural 
value in light of aestheticization or aesthetic practices. Reflecting the fruits of the Research Council of Norway's comprehensive programme for cultural research (KULVER), this anthology studies cultural phenomena not as static dimensions, but rather as factors involved in negotiations and exchanges. By examining the processes in which aestheticization is prominent, the contributors show how the experience-based, relational, and perceptual aspects of assigning cultural values come into focus. Each of the essays offers dufferent perspectives on the value given to different cultural phenomena, by focusing on their historically changeable aspects, their reciprocal relationships, and their connection to social contexts and power. Drawing on case studies from the fields of cultural history, aesthetics, literature, film, gender studies, art history and theory, design history, and museology, the collection provides a wide-ranging and multifaceted analysis of how the assignment of cultural values is changed, displaced, transferred, and acquired.

Contents: Adam Dodd: Size is in the Eye of the Beholder: On the Cultural History of Microfaunae in Seventeenth-Century Europe - Anja Johansen: Awarding Images, Celebrating Science: The Aesthetics and Aestheticization of Scientific Images in the Wellcome Image Awards - Jørgen Lorentzen/Wencke Mühleisen: Intimacy and Sexuality in Two Contemporary Norwegian Novels - Geir Uvsløkk: Politics and Aesthetics in Michel Houellebecq's Novels - Anne Gjelsvik: From Hard Bodies to Soft Daddies: Action Aesthetics and Masculine Values in Contemporary American Action Films - Gry Brandser: The Bearded Ladies of Learning - Kjetil Fallan: Culture by Design: Co-Constructing Material and Meaning - Frode Helland/Julie Holledge: A Doll's House as National Tradition: Understanding the Construction of Aesthetic Value - Søren Kjørup: Art as the Other? Reflections on Craft's and Fine Art's Places in the Aesthetic Field - Mari Hvattum/Brita Brenna/Torild Gjesvik/Janike Kampevold Larsen: The King's Road: Constructing the Modern Landscape - Johan Schimanski/Stephen F. Wolfe: The Aesthetics of Borders - Stefan Krankenhagen: Collecting Europe: On the Museal Construction of European Objects - Anne Britt Ylvisåker: Digitising the Valuable - Valuing the Digiti.

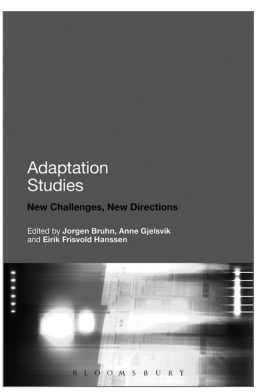

\section{Adaptation Studies} New Challenges, New Directions

\section{Jørgen Bruhn, Anne Gjels-} vik \& Eirik Frisvold Hanssen (red.). London: Bloomsbury Academic, 2013. 304 s. ISBN 9781441192660

Extending the boundaries of contemporary adaptation studies, this book brings together international scholars to survey new directions in the field. Re-thinking the key questions at the heart of the discipline, Adaptation Studies: New Directions, New Challenges explores a wide range of perspectives and case studies in cross-media transformation. Topics covered include: The history of adaptation studies, Theories of adaptation, Adaptations in film, literature, radio and historical sources, What is an 'original' text?

Content: Introduction, Jørgen Bruhn, Anne Gjelsvik, and Eirik Frisvold Hanssen Part I: Rethinking the Core Questions 1. Theorizing Adaptations/Adapting Theories, Kamilla Elliott 2. Adaptation and Adaptive Revision: The Problem of Textual Identity, John Bryant 3. Dialogizing Adaptation Studies: From One Way Transport to a Dialogic Process, Jørgen Bruhn 4. Adaptation as Connection: Transmediality Reconsidered, Regina Schober 5. Adaptations within the Field of Media Transformations, Lars Elleström 6. Imaginary Museums: André Bazin, Film Theory and Adaptation, Eirik Frisvold Hanssen 7. What Movies Want, Tom Leitch Part II: Theorizing the Case-Study 8. The Medium Strikes Back: 'Impossible Adaptation' Revisited, Hajnal Kiraly 9. 'Pre-Texts': The Notebook Case (Bergman), Anna Sofia Rossholm 10. Tracing the Original: The Film Invictus and "Based on a True Story" Adaptation, Sara Brinch 11. What Novels Can Tell That Movies Can't Show, Anne Gjelsvik 12. Literature Through Radio: Distance, Silence and Media Archaeology: The War of the Worlds 1938/1898, Jonas Ingvarsson

\section{Eastwood's Iwo Jima}

\section{A Critical Engagement with Flags of Our Fathers and Letters From Iwo Jima}

Anne Gjelsvik \& Rikke Schubart (red.). London: Wallflower Press, 2013. 250 s. ISBN 978-0-231-16565-5.

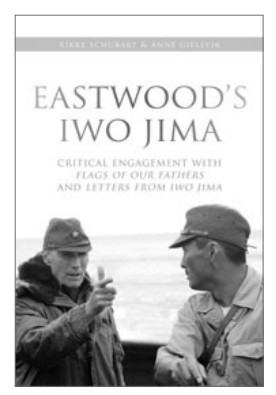

With Flags of Our Fathers (2006) and Letters from Iwo Jima (2006), Clint Eastwood made a unique contribution to film history, being the first director to make two films about the same event. Eastwood's films examine the battle over Iwo Jima from two nations' perspectives, in two languages, and embody a passionate view on conflict, enemies, and heroes. Together these works tell the story behind one of history's most famous photographs, Leo Rosenthal's "Raising the Flag on Iwo Jima." In this volume, international scholars in political science and film, literary, and cultural studies undertake multifaceted investigations into how Eastwood's diptych reflects war today. Fifteen essays explore the intersection among war films, American history, and Japanese patriotism. They present global attitudes toward war memories, icons, and heroism while offering new perspectives on cinema, photography, journalism, ethics, propaganda, war strategy, leadership, and the war on terror. 


\section{Religion across Media}

From Early Antiquity to Late Modernity.

Knut Lundby (red.). New York: Peter Lang, 2013. 215 s. ISBN 978-1-4331-2077-0.

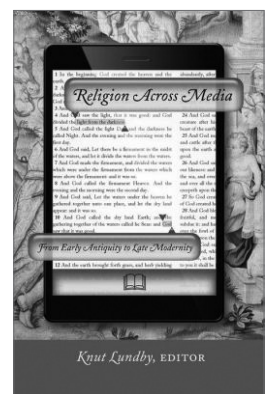

This edited collection aims to examine religion across: historical media forms using a broad concept of «media»; contemporary media with a focus on digital forms; religious traditions; disciplinary approaches. The focus here is on processes of mediation rather than «media» as such. Religion is seen as intertwined in forms of mediation that possibly transform religious practices. Analytical insights from the field of media studies are brought to bear on religion in ancient media, such as ritual or early manuscript culture. Insights from such analyses provide a strengthened awareness of continuities and discontinuities between the (post-) modern and earlier societies to the study of current media and religion. This book attempts to address issues of religion and media precisely through establishing a cross-disciplinary scholarly dialogue on the subject of «religion across media».

Contents: Birgit Meyer: Material Mediations and Religious Practices of World-Making, Terje Stordalen: Media of Ancient Hebrew Religion, Peter Horsfield: The Ecology of Writing and the Shaping of Early Christianity, Liv Ingeborg Lied: Manuscript Culture and the Myth of Golden Beginnings , Ute Hüsken: Contested Ritual Mediation: Brahmin Temple Priests in South India ,Peter Simonson: On Digital Eloquence and Other Rhetorical Pathways to Thinking About Religion and Media, Kim Knott: Religion, Space, and Contemporary Media, David Thurfjell: Mediating Gypsiness Through the Holy Spirit: Pentecostalism and Social Mobilization Among European Roma, Nabil Echchaibi: Taming the West: Mediations of Muslim Modernities, Mia Lövheim: New Media, Religion, and Gender: Young Swedish Female Bloggers - Stewart M. Hoover: Evolving Religion in the Digital Media, Knut Lundby: Media and Transformations of Religion.

\section{Other new literature}

Staksrud, E., Olafsson, K., Green, L., Brady, D., \& Holloway, D. (2013). What bothers Australian kids online?: children comment on bullies, porn and violence. Perth: Edith Cowan University Australia.

\section{Articles}

Adams, P. C., \& Gynnild, A. (2013). Environmental messages in online media: the role of place. Environmental Communication: A Journal of Nature and Culture, 7(1), 113-130.

Berne, S., Frisén, A., Schultze-Krumbholz, A., Scheithauer, H., Naruskov, K., Piret, L., Catarina, K., Erentaite, R., \& Zukauskiene, R. (2013). Cyberbullying assessment instruments: A systematic review. Aggression and Violent Behavior, (18), 320-334.

Bruhn, J., \& Gjelsvik, A. (2013). David Simon's novel cop show. New Review of Film and Television Studies, 11(2), 133-153.

Cheong, P. H., \& Ess, C. (2012). Introduction: religion 2.0 ? relational and hybridizing pathways in religion, social media, and culture. I Cheong, P. H., FischerNielsen, P., Gelfgren, S., \& Ess, C. (red.), Digital religion, social media and culture. Kapitel 1. (s. 1-21). New York: Peter Lang.

Dahlén, P. (2013). The geopolitics of failure: Swedish journalism and the demise of the national ice hockey team in Salt Lake City, 2002. Sport in Society: Cultures, Commerce, Media, Politics, 16(5), 579-594.
Enli, G., Moe, H., Sundet, V. S., \& Syvertsen, T. (2013). From fear of television to fear for television: five political debates about new technologies. Media History, 19(2), 213-227.

Enli, G. (2013). Defending Nordic children against Disney: PSB children's channels in the age of globalization. Nordicom Review, 34(1), 77-90.

Frey, E. (2013). Norway's media coverage: the salute of a man who does not regret. Journal of Mass Media Ethics, 28(1), 59-61.

Frey, E. (2013). Renegotiating online news: journalism in the classroom. Nordicom Review, 34(1), 17-31

Gjelsvik, A. (2013). Care or glory?: picturing a new war hero. I Gjelsvik, A., \& Schubart, R. (red.), Eastwood's Iwo Jima. Kapitel 2. London: Wallflower Press.

Gjelsvik, A. (2013). From hard bodies to soft daddies: action aesthetics and masculine values in contemporary American action films. I Aukrust, K. (red.), Assigning cultural values. Frankfurt am Main: Peter Lang.

Gjelsvik, A. (2013). What novels can tell that films can't show. I Bruhn, J., Gjelsvik, A., \& Hanssen, E. F. (red.), Adaptation studies. Kapitel 11. London: Bloomsbury Academic.

Gjelsvik, A., Bruhn, J., \& Hanssen, E. F. (2013). 'There and back again': new challenges and new directions in adaptation studies. I Bruhn, J., Gjelsvik, A., \& Hanssen, 
E. F. (red.), Adaptation studies. Kapitel 1.(s. 1-16). London: Bloomsbury Academic.

Gjelsvik, A. (2013). Introduction: know your enemy, know yourself. I Gjelsvik, A., \& Schubart, R. (red.), Eastwood's Iwo Jima. (s. 1-14). London: Wallflower Press.

Grønstad, A. (2013). Abbas Kiarostami's Shirin and the Aesthetics of Ethical Intimacy. Film Criticism, 37, 22-37.

Gustafsson, H. (2013). Foresight, hindsight and state secrecy in the American West: the geopolitical aesthetics of Trevor Paglen. Journal of Visual Culture, 12(1), 148-164.

Gynnild, A., \& Adams, P. C. (2013). Animation, documentary or interactive gaming?: exploring communicative effects of environmental messaging online. \#ISOJ Journal , 3(1).

Gynnild, A. (2013). Journalism innovation leads to innovation journalism: the impact of computational exploration on changing mindsets. Journalism: theory, practice \& criticism, 1-18.

Gynnild, A. (2013). Surveillence videos and visual transparency in journalism. Journalism Studies, 1-15.

Hanssen, E. F. (2013). The hidden spaces of the theatre in George Cukor's A Double Life. La Furia Umana, (2), 54-49.

Hanssen, E. F. (2013). Imaginary museums, material refractions: André Bazin on adaptation. I Bruhn, J., Gjelsvik, A., \& Hanssen, E. F. (red.), Adaptation studies. Kapitel 7.(s. 133-153 ). London: Bloomsbury Academic.

Haug, K. H., Jamissen, G., \& Ohlmann, C. (2012). Den kreative fortellerprosessen - story circle. I Haug, K. H., Jamissen, G., \& Ohlmann, C. (red.), Digitalt fortalte historier. (s. 165-168). Oslo: Cappelen Damm AS.

Hoelzl, I. (2012). Moving stills: the Ken Burns effect. I Hoelzl, I., \& Tietjen, F. (red.), Images in Motion. Kapitel 5.(s. 55-62). Brussels: Luca School of Arts Brüssel.

Karlsen, J., \& Stavelin, E. (2013). Computational journalism in Norwegian newsrooms. Journalism Practice.

Kjeldsen, J. E. (2013). Strategies of visual argumentation in slideshow presentations: the role of the visuals in an Al Gore presentation on climate change. Argumentation: an international journal on reasoning.

Kjeldsen, J. E. (2013). Speaking to Europe: a rhetorical approach to prime minister Tony Blair's speech to the EU Parliament. I Fløttum, K. (red.), Speaking of Europe. (s. 19-42). Amsterdam: John Benjamins Publishing Company.
Krumsvik, A. H., Skogerbø, E., \& Storsul, T. (2013). Size, ownership and innovation in newspapers. I Storsul, T., \& Krumsvik, A. H. (red.), Media Innovations. (s. 93-109). Göteborg: Nordicom, Göteborgs universitet.

Krumsvik, A. H. (2013). Towards a typology of strategies for user involvement. I Friedrichsen, M., \& Mühl-Benninghaus, W. (red.), Handbook of social media management. (s. 655-669). Berlin, Heidelberg: Springer Berlin / Heidelberg.

Krumsvik, A. H. (2012). Impact of VAT on portfolio strategies of media houses. Journal of Media Business Studies, 9(2), 115-128.

Krumsvik, A. H. (2012). Why old media will be funding journalism in the future. Journalism Studies, 13(5-6), 729-74.

Kvidal, T., \& Ljunggren, E. (2012). Implementing “a gender perspective" in an innovation program. I Promoting innovation. (s. 111-130). Vinnova.

Larssen, K., \& Hornmoen, H. (2013). The literary journalist as fellow human being. Literary Journalism Studies, 5(1), 81-96.

Larsson, A. O. (2012). Tweeting the viewer: use of Twitter in a talk show context. Journal of Broadcasting \& Electronic Media, 57(2), 135-152.

Larsson, A., \& Moe, H. (2013). Representation or Participation?. Javnost - The Public, 20, 71-88.

Lavik, E., \& van Gompel, S. (2013). Quality, merit, aesthetics and purpose: an inquiry into EU copyright law's eschewal of other criteria than originality. Revue Internationale du Droit d'Auteur, (236), 100-295.

Lavik, E., \& van Gompel, S. (2013). On the prospects of raising the originality requirement in copyright law: perspectives from the humanities. Journal of the Copyright Society of the U.S.A., 60(3).

Liestøl, G. (2013). Topics of innovation: towards a method of invention and innovation in digital media design. I Storsul, T., \& Krumsvik, A. H. (red.), Media innovations. Kapitel 4.(s. 61-74). Gøteborg: Nordicom, Göteborgs universitet.

Lundby, K. (2013). Introduction: religion across media. I Lundby, K. (red.), Religion across media. (s. xi-xxiii). New York: Peter Lang.

Lundby, K. (2013). Media and Transformations of religion. I Lundby, K. (red.), Religion across media. (s. 185-202). New York: Peter Lang.

Moe, H., \& Mjøs, O. J. (2013). The arm's length principle in Nordic public broadcasting regulation. I Carlsson, 
U. (red.), Public service media from a Nordic horizon. Kapitel 4.(s. 75-92). Nordicom, Göteborgs universitet.

Moe, H., \& Larsson, A. (2013). Untangling a complex media system: a comparative study of Twitterlinking practices during three Scandinavian election campaigns. Information, Communication and Society, 16(5), 775-794.

Moe, H. (2013). Public service broadcasting and social networking sites: the Norwegian Broadcasting Corporation on Facebook. Media International Australia, (146), 114-122.

Orgeret, K., Krøvel, R. G., \& Ytterstad, A. (2012). Objectivity and advocacy in global warming journalism: scientific knowledge, local experiences and concern among students in Nicaragua, Nepal and Bangladesh. Asia Pacific Media Educator, 22(1), 15-28.

Rye, S. A. (2013). Connected youth: young students' extensibility and use of the Internet to search for information. Nordicom Review, 34 (1), 33-48.

Simonsen, A. H. (2012). I Kens hus. I Krøvel, R., \& Orgeret, K. S. (red.), Historier om verden. (s. 57-60). Kristiansand: IJ-forlaget.

Sjøvaag, H. (2013). The meaning and function of journalistic ideology. I Trivundža, I. T., Carpentier, N., Nieminen, H., Pruulmann-Venerfeldt, P., Kilborn, R., Sundin, E., \& Olsson, T. (red.), Past, future and change. (s. 135-146). Faculty of Social Sciences, University of Ljubljana Press: Založba FDV.

Skjerdal, T. S. (2013). Selective liberalization: an analysis of media reform in an emerging democracy. I Olorunnisola, A., \& Douai, A. (red.), New media influence on social and political change in Africa. Kapitel 3.(s. 32-50). Hershey, Pennsylvania: IGI Global.

Spilker, H. S., \& Høier, S. (2013). Technologies of piracy?: exploring the interplay between commercialism and idealism in the development of MP3 and DivX. International Journal of Communication, 7, 2067-2086.
Staksrud, E., Livingstone, S., \& Ólafsson, K. (2013). Does the use of social networking sites increase children's risk of harm?. Computers in Human Behavior, 29(1), 40-50.

Staksrud, E., \& Kirksæther, J. (2013). 'He who buries the little girl wins!' Moral panics as double jeopardy.: the case of Rule of Rose.I Petley, J., Critcher, C., Hughes, J., \& Rohloff, A. (red.), Moral panics in the contemporary world. (s. 145-167). London: Bloomsbury Academic.

Steensen, S. (2013). Balancing the bias: the need for counter-discursive perspectives in media innovation research . I Storsul, T., \& Krumsvik, A. H. (red.), Media innovation. Kapitel 3.(s. 45-59). Gøteborg: Nordicom, Göteborgs universitet.

Storsul, T., \& Krumsvik, A. H. (2013). What is media innovation?. I Storsul, T., \& Krumsvik, A. H. (red.), Media innovations. (s. 13-26). Gøteborg: NORDICOM.

Sørenssen, B. (2013). The forgotten cinematographer of Mount Suribachi: Bill Genaust's eight-second Iwo Jima Footage and the historical facsimile. I Gjelsvik, A., \& Schubart, R. (red.), Eastwood's Iwo Jima. (s. 36-57 ). London: Wallflower Press.

Tessem, B., \& Nyre, L. (2013). The influence of social media use on willingness to share location information. Lecture Notes in Computer Science, 8058, 161-172.

Thorbjørnsrud, K. (2013). The autonomy of Scandinavian public service broadcasters during election campaign periods: principles and practices. Nordicom Review, 13(1), 63-76.

Tomaselli, K., Mboti, N., \& Rønning, H. (2013). SouthNorth perspectives: the development of cultural and media studies in Southern Africa. Media Culture and Society, 35(1), 36-43.

Vaage, M. B. (2013). Fictional reliefs and reality checks. Screen, 54(2), 218-237.

\section{www.nordicom.gu.se/eng.php?portal $=$ mr\&main $=$}




\section{Sweden \\ Documentalist: Maria Edström}

\section{Traditional Bullying and Cyberbullying among Swedish Adolescents}

\section{Gender Differences and Associations with Mental Health}

Linda Beckman, Karlstad, 2013. 100 s. ISBN 978-917063-509-0. Doctoral Dissertation.

The overall aim of this thesis is to study the differences between traditional bullying and cyberbullying among adolescents, focusing on gender, psychosomatic problems, and disability. The aim is also to gain insight into health staff's experience of bullying in schools. The thesis is based on four studies based on surveys undertaken among 3,800 adolescents in Grades 7, 8 and 9 in Sweden, as well as focus groups of 16 people consisting of school social workers and school nurses. While almost no gender differences were found among traditional victims, Study I showed that girls were more likely than boys to be cybervictims. Boys were more likely than girls to be traditional bullies, while girls were equally as likely as boys to be cyberbullies. Study II showed that psychosomatic problems were associated with being a victim, a bully or a bully-victim. Cyberbullying showed no stronger association with psychosomatic problems than traditional bullying.

\section{Knowledge at Play \\ Studies of Games as Members' Matters}

Ulrika Bennerstedt, Acta Universitatis Gothoburgensis, 2013. 261 s. ISBN 978-91-7346-742-1. Doctoral Dissertation.

On a general level, this thesis seeks some answers to the broad question of what one can learn from digital games. With an analytical approach informed by ethnomethodology, the main thrust of the work is an exploration of members' matters in the area of games and gaming. In response to prevailing discussions about how, where and what gamers learn, the aim is to examine emerging forms of knowledge embedded in practices in and around digital games. The first part of the thesis addresses three themes: the question of whether leisure gaming could be understood to have transfer effects; how games are positioned in a state of restlessness and multistableness; and how the domain encompassing gaming and game development is advancing in terms of professionalization and institutionalization. The second part is comprised of three empirical studies based on two sets of video recordings: collaborative gaming in The Lord of the Rings Online, and assessment practices in game development education. The studies begin to unravel the elusive phenomena of gaming by making some gameplay practices and conventions visible. For instance, the findings suggest that there are specialized coordination practices, developed through long-term engagement with the online game.

\section{Global Journalism}

Theory and Practice

Peter Berglez, New York: Peter Lang Publishing Group, 2013. 156 s. ISBN 978-1-4331-1030-6.

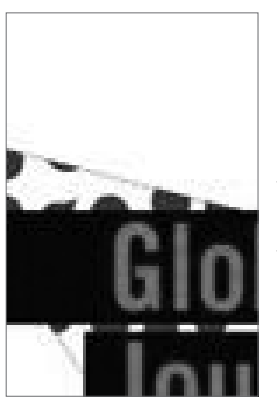

Recent instances of global crisis reporting on climate change and the financial crisis are early embryos of a new form of journalism that is increasingly needed in global times: global journalism. Instead of associating global journalism with national comparisons of media systems or defining it as an ethically «corrective» form of journalism, Berglez sets out to develop the idea of global journalism as an epistemological updating of everyday mainstream news media. He argues that the future of professional news journalism is about leaving behind the dominant national outlook for the sake of a more integrated (global) outlook on society. Emerging examples of global journalism are analyzed throughout the book alongside the historical background and the challenges it faces.

\section{Being a Young Citizen in Estonia}

An Exploration of Young People's Civic and Media Experiences

Anne Kaun, Tartu: University of Tartu, 2013. 133 s. ISBN 978-9949-32-274-9.

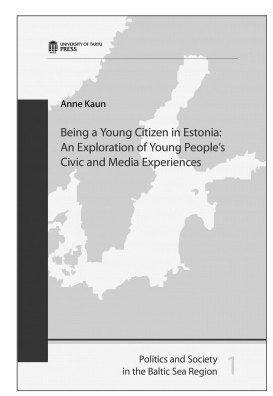

The book gives an insight into how young people in Estonia, twenty years after the establishment of democracy, perceive their own role as citizens. It does so in a theoretical framework that stresses the embeddedness of the civic experiences in a media-dominated environment, thus closely linking civic and media experiences. Based on the analysis of both qualitative interview data and a relatively new method of using the internet as a complementary tool for engaging with open-ended diaries, the study explores the extent to which young citizens experience the media as being interwoven with their everyday lives and, in fact, constitutive of their social reality as citizens. 


\section{Media and Memory in New Shanghai} Western Performances of Futures

Amanda Lagerkvist, Palgrave Macmillan, 2013. 208 s. ISBN 978-1137014641.

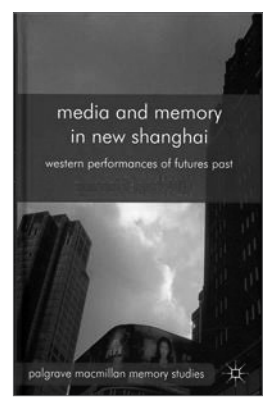

Contributing to current debates about the globality and mediatization of memories, Lagerkvist critically interrogates Shanghai's spectacular resurrection into an emergent world center from the vantage point of how Western elites (tourists, expatriates and travel bloggers) partake in the production of New Shanghai. Through performances of memory, Westerners consume the regenerative nostalgia of the city. This book shows that these mediatized memory practices become essential for the city and tie in with how the municipal government (in tandem with international scriptings of the city in for example films and travel journalism) is currently theming Shanghai by situating memories of futures past and visions for the future in a coherent narrative and sensory-emotive realm of experience.

\section{Media Talk and Political Elections in Europe and America}

Mats Ekström \& Andrew Tolson (red.), Palgrave, 2013. 256 s. ISBN 978-1-137-27331-4.

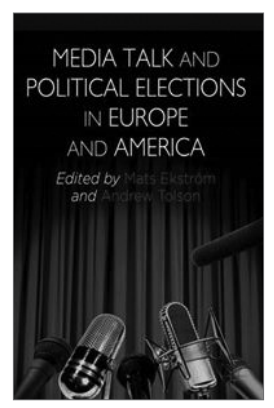

This book provides a analysis of forms of media talk associated with contemporary political elections. The approach is derived from the study of broadcast media talk, which extends here to political communication on the Internet. Key topics include: changing forms of political interview, televised political debates (held in the UK for the first time in 2010), the use of multimedia in promotional discourse, and uses of the Internet to engage with voters (an approach used successfully in the Obama presidential campaigns of 2008 and 2012). In addition to chapters from the UK and USA, there are also contributions from Greece, Spain, Sweden and Austria.

\section{Transnational Ecocinema}

Film Culture in an Era of Ecological Transformation

Tommy Gustafsson \& Pietari Kääpä (red.) Bristol och Chicago: Intellect Ltd, 2013. 228 s. ISBN 978-1-84150729-3.

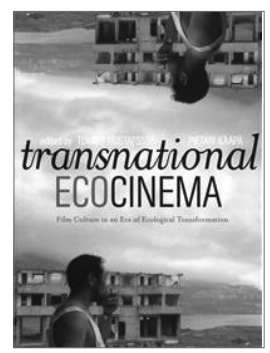

Discussion of Hollywood film has dominated much of the contemporary dialogue on ecocriticism and the cinema-until now. With Transnational Ecocinemas, the editors open up the critical debate to look at a larger variety of films from many different countries and cultures. By foregrounding these films with their economic and political contexts, the contributors offer a more comprehensive and nuanced look at the role of place in ecocinema. The essays also interrogate proposed global solutions to environmental issues by presenting an ecocritical perspective on different film cultural considerations from around the globe.

\section{New Noise}

A Cultural Sociology of Digital Disruption

Simon Lindgren, New York: Peter Lang Publishing Group, 2013. 176 s. ISBN 978-1433119941.

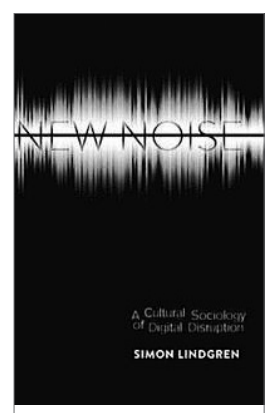

This book is about online subcultures thriving in the border zones between pop cultural and political engagement. Combining classic theories of space, power and resistance with current case studies of digital piracy, online activism and remix culture, the book develops a cultural theory of social movements in the digital age. 


\section{Other new literature}

\section{Artiklar}

Adam, S., Maier, M., De Vreese, C. H., Schuck, A. R. T., Stetka, V., Jalali, C., Seeber, G. U. H., Negrine, R., Raycheva, L., Berganza, R., Róka, J., Dobek-Ostrowska, B., Nord, L., Balzer, M., \& Baumli, M. (2013). Campaigning Against Europe?: The Role of Euroskeptic Fringe and Mainstream Parties in the 2009 European Parliament Election. Journal of Political Marketing, 12(1), 77-99.

Andersson, L. G., Sundholm, J., \& McParland, R. P. (red.) (2013). Reluctant Swedish modernism: Transnational trajectories and domestic applications. I Film and Literary Modernism. (s. 61-72). Cambridge Scholars Publishing.

Anden-Papadopoulos, K. (2013). Media witnessing and the crowd-sourced video revolution'. Visual Communication, 12(3), 341-357.

Andersson, U., \& Wiik, J. (2013). Journalism Meets Management: Changing Leadership in Swedish News Organizations. Journalism Practice, 7.

Andersson, U. (2013). Maintaining Power by Guarding the Gates: Journalists' Perceptions of Audience Participation in Online Newspapers. Journalism and Mass Communication, 3(1), 1-13.

Arnberg, K. (2013). For Men, by Men? Women's Business Activities in the Pornographic Press Compared to the Overall Publishing Industry in Sweden 1950-1972. NORA : Nordic Journal of Feminist and Gender Research, 21(1), 21-40.

Askanius, T. (2013). Protest movements and spectalcles of death. Research in social movements conflict and change, 105-133.

Askanius, T., \& Uldam, J. (2013). Online Civic Cultures: Debating Climate Change Activism on YouTube. International Journal of Communication, 7.

Barrett, J. (2013). Virtual worlds, machinima and cooperation over borders. Sens Public: International Web Journal.

Barrett, J. (2013). Virtual Worlds and Indigenous Narratives. I The Immersive Internet : Reflections on the Entangling of the Virtual with Society, Politics and the Economy. (s. 77-92). Palgrave Macmillan.

Becker, K. (2013). Performing the News. Photographies, 6(1), 17-28.

Bergman, K., Andrew, L. (red.), \& Phelps, C. (red.) (2013). From National Authority to Urban Underbelly: Negotiations of Power in Stockholm Crime Fiction. I Andrews, L., \& Phelps, C. (red.), Crime Fiction in the City: Capital Crimes. (s. 65-84). University of Wales Press.

Bergman, K., \& Martin, R. (red.) (2013). From “The Case of the Pressed Flowers" to the Serial Killer's Torture Chamber: The Use and Function of Crime Fiction Sub-Genres in Stieg Larsson's The Girl with the Dragon Tattoo. I Critical Insights: Crime and Detective Fiction. Salem Press.

Bergman, K., Schoenhals, M. (red.), \& Sarsenov, K. (red.) (2013). The Good, The Bad, and the Collaborators: Swedish World War II Guilt Redefined in 21st Century Crime Fiction. I Imagining Mass Dictatorships: The Individual and the Masses in Literature and Cinema. (s. 183-210).

Berne, S., Frisén, A., Schultze-Krumbholz, A., Scheithauer, H., Naruskov, K., Piret, L., Catarina, K., Erentaite, R., \& Zukauskiene, R. (2013). Cyberbullying assessment instruments: A systematic review. Aggression and Violent Behavior, (18), 320-334.

Bo, N., \& Carlsson, E. (2013). Swedish politicians and new media: Democracy, identity and populism in a digital discourse. New Media and Society.

Bogren, A. (2013). Symbolic Gender Boundaries in News Discourse on Psychotropics Use and Drinking: An Analysis of the Swedish Press Debate 2000-2009. NORA : Nordic Journal of Feminist and Gender Research, 21(1), 57-73.

Cahir, J., \& Werner, A. (2013). Escaping the everyday: Young people's use of text messages and songs. Youth Studies Australia, 32.

Dahlberg, L. (2013). A Modern Trial: A Study of the Use of Video-Recorded Testimonies in the Swedish Court of Appeal. Studies in Law, Politics, and Society, 61, 81-135.

Dahlgren, P. (2013). Online Journalism and Civic Cosmopolitanism: Professional vs. participatory ideals. Journalism Studies, 14(2), 156-171.

Dahlgren, P. (2013). Tracking the Civic Subject in the Media Landscape: Versions of the Democratic Ideal. Television and New Media, 14(1), 71-88.

Edström, M (2013) Sweden: Women Reach Parity but Gender Troubles Persist, I Carolyn M. Byerly (red), The Palgrave International Handbook of Women and Journalism. Palgrave Macmillan.

Ekström, M., \& Östman, J. (2013). Family talk, peer talk, and young people's civic orientation. European Journal of Communication, 28(3), 294-308. 
Ekström, M., \& Fitzgerald, R. (2013). Groundhog day: Extended Repetitions in Political News Interviews. Journalism Studies.

Ekström, M., \& Östman, J. (2013). Information, interaction, and creative production: The effects of three forms of Internet use on youth democratic engagement. Communication Research.

Fauville, G., Lantz-Andersson, A., \& Säljö, R. (2013). ICT tools in environmental education: reviewing two newcomers to schools. Environmental Education Research.

Grünberg, J., \& Pallas, J. (2013). Beyond the news desk: The embeddedness of business news. Media Culture and Society, 35(2), 216-233.

Gunnarsson Payne, J. (2013). Moving images, transforming media: The mediating communitas of Hallon TV and DYKE HARD. International Journal of Cultural Studies, 16(4), 367-382.

Hedling, O. (2013). «An Unintended Effect of the Introduction of the Public Support Systems» - Film policy, film support and the contemporary Scandinavian production landscape. The Nordic Journal of Cultural Policy/Nordisk kulturpolitisk tidskrift, 16, 90-104.

Hedling, E., Svartvik, J. (red.), \& Wirén, J. (red.) (2013). Joseph, Goebbels, Kristina Söderbaum and Jud Süss: Seventy Years later. I Religious Stereotyping and Interreligious Relations. Palgrave Macmillan.

Hedman, U., \& Djerf-Pierre, M. (2013). The social journalist: Embracing the social media life or creating a new digital divide?. Digital Journalism, 1-18.

Hohenthal, C., Moberg, Å., Arushanyan, Y., Ovaskainen, M., Nors, M., \& Koskimäki, A. (2013). Environmental performance of Alma Media's online and print products. Finland: VTT.

Jansson, A. (2013). A Second Birth?: Cosmopolitan Media Ethnography and Bourdieu's Reflexive Sociology. International Journal of Cultural Studies, 16(2), 135-150.

Jansson, A. (2013). The Hegemony of the Urban/Rural Divide: Cultural Transformations and Mediatized Moral Geographies in Sweden. Space and Culture, 15(1), 88-103.

Kaun, A. (2013). Playful Public Connectivity and Heritage Institutions. I Runnel, P., Prullman-Vengerfeldt, P., Viires, P., \& Laak, M. (red.), The Digital Turn : Users Practices and Cultural Transformations Peter Lang Publishing Group.

Kaun, A. (2013). Citizenship und Partizipation. I Handbuch Cultural Studies und Medienanalyse. VS Verlag.
Kroon Lundell, Å., Ekström, M., Eriksson, G., \& Lundell, Å. K. (2013). Live co-produced news: emerging forms of newsproduction and presentation on the web. Media Culture and Society, 35(5), 620-639.

Kroon Lundell, Å., \& Ekström, M. (2013). Interpreting the news: Swedish correspondents as expert sources 1982-2012. Journalism Practice. Zuiderveld, M. (2013). Sex, Football and the Media: The case of South Africa and the World Cup 2010. Scandinavian Sport Studies Forum, 4, 25-48. Kylhammar, M. (2013). Les prix Nobel de littérature et les medias. Le paradigme du modèle suédois. I La Nord à la lumière du Sud. (s. 5-25). Deshima. Lagerkvist, A. (2013). Communicating the rhythms of retromodernity: 'confused and mixed Shanghai'. Sociological Review, 61, 144-161.

Larsson, A. O. (2013). 'Rejected bits of program code': Why notions of "politics 2.0" remain (mostly) unfulfilled. Journal of Information Technology \& Politics, $10(1), 72-85$.

Larsson, A. O. (2012). Tweeting the viewer: use of Twitter in a talk show context. Journal of Broadcasting \& Electronic Media, 57(2), 135-152.

Larsson, A., \& Moe, H. (2013). Representation or Participation?. Javnost The Public, 20, 71-88.

Larsson, S. (2013). Metaphors, Law and Digital Phenomena: the Swedish pirate bay court case. International Journal of Law and Information Technology, 1-26.

Lidskog, R., \& Olausson, U. (2013). To spray or not to spray: the discursive construction of contested environmental issues in the news media. Discourse, Context \& Media, 2(3), 123-130.

Linderoth, J. (2013). Beyond the digital divide: An ecological approach to gameplay. Transactions of the Digital Games Research Association, 1.

Linderoth, J. (2013). Games, sports and sport videogames. I Consalvo, M., Mitgutsch , K., \& Stein, A. (red.), Sports Videogames. (s. 15-31). Routledge.

Lindgren, S. (2013). The Potential and Limitations of Twitter Activism: Mapping the 2011 Libyan Uprising. tripleC (cognition, communication, co-operation) : Journal for a Global Sustainable Information Society / Unified Theory of Information Research Group, 11(1), 207-220.

Lindgren, S. (2013). Sub*culture: Exploring the dynamics of a networked public. Transformative Works and Cultures.

Lunde, C. (2013). Acceptance of Cosmetic Surgery, Body Appreciation, Body Ideal Internalization, and Fashion Blog Reading among Late Adolescents in Sweden. Body image. 
Lundgren, F. (2013). The politics of participation: Francis Galton's Anthropometric laboratory and the making of civic selves. British Journal for the History of Science, 46(3), 445-466.

Miegel, F., \& Olsson, T. (2013). Civic Passion : A Cultural Approach to the 'Political'. Television and New Media, 14(1), 5-19.

Moe, H., \& Larsson, A. (2013). Untangling a complex media system: a comparative study of Twitterlinking practices during three Scandinavian election campaigns. Information, Communication and Society, 16(5), 775-794

Nord, L. (2013). Newspaper Competition and Content Diversity: A Comparison of Regional Media Markets in Sweden. Papeles de Europa, 26(1), 1-13.

Nord, L., \& Arriaza Ibarra, K. (2013). Still Something Special?: A Comparative Study of Public Service Journalists' Values in Spain and Sweden. Journal of Applied Journalism and Media Studies, 2(1), 161-179.

Olausson, U. (2013). Theorizing global media as global discourse. International Journal of Communication, 7, 1281-1297

Olsson, J. (2013). Screen Bodies and Busybodies: Corporeal Constellations in the Era of Anonymity. Film History. An International Journal, 25, 188-204.

Olsson, E. J., \& Vallinder, A. (2013). Norms of Assertion and Communication in Social Networks. Synthese.

Olsson, T., Svensson, A., (2013). Reaching and Including Digital Visitors: Swedish Museums and Social Demand. I Runnel, P., Prullman-Vengerfeldt, P., Viires, P., \& Laak, M. (red.), The Digital Turn: User's Practices and Cultural Transformations. Peter Lang.

Olsson, T., Viscovi, D., Tomanic Trivundza, I. (red.), Carpentier, N. (red.), Nieminen, H. (red.), PruulmannVengerfeldt, P. (red.), Kilborn, R. (red.), \& Sundin, E. (red.) (2013). Impediments to Participation: UGC and Professional Culture. I Past, Future and Change: Contemporary Analysis of Evolving Media Scapes. (s. 283-295).

Pallas, J., \& Fredriksson, M. (2013). Corporate Media Work and Micro-Dynamics of Mediatization. European Journal of Communication, 28(4), 420-435.

Petersson McIntyre, M. (2013). Perfume Packaging, Seduction and Gender. Culture Unbound. Journal of Current Cultural Research, 5, 291-311.

Raviola, E., \& Norbäck, M. (2013). Bringing Technology and Meaning into Institutional Work: Making News at an Italian Business Newspaper. Organization Studies, 34(8), 1171-1194.
Robertson, A. (2013). Connecting in Crisis: 'Old' and 'New' Media and the Arab Spring. The International Journal of Press/Politics.

Roosvall, A., \& Tegelberg, M. (2013). Framing climate change and indigenous peoples: intermediaries of urgency, spirituality and de-nationalization. International Communication Gazette, 75(4), 392-409.

Shehata, A. (2013). Active or Passive Learning From Television?: Political Information Opportunities and Knowledge Gaps During Election Campaigns. Journal of Elections, Public Opinion, and Parties, 23(2). 200-222.

Shehata, A., \& Strömbäck, J. (2013). Not (Yet) a New Era of Minimal Effects: A Study of Agenda Setting at the Aggregate and Individual Levels. The International Journal of Press/Politics, 18(2), 234-255. Simonson, Ö. (2013). Information costs and commercial integration: The impact of the 1692 Swedish postage tariff. Scandinavian Economic History Review, 61(1), 60-81.

Strömbäck, J., Grandien, C., \& Falasca Larsson, K. (2013). Do Campaign Strategies and Tactics Matter? Exploring Party Elite Perceptions of What Matters When Explaining Election Outcomes. Journal of Public Affairs, 13(1), 41-52.

Strömbäck, J., Negrine, R., Hopmann, D. N., Jalali, C., Berganza, R., Seeber, G. U. H., Seceleanu, A., Volek, J., Dobek-Ostrowska, B., Mykkänen, J., Belluati, M., \& Maier, M. (2013). Sourcing the News: Comparing Source Use and Media Framing of the 2009 European Parliamentary Elections. Journal of Political Marketing, 12(1), 29-52.

Strömbäck, J., \& van Aelst, P. (2013). Why Political Parties Adapt to the Media: Exploring the Fourth Dimension of Mediatization. International Communication Gazette, 75(4), 341-358.

Svensson, M., Larsson, S., de Kaminski, M., Braga, R. (red.), \& Caruso, G. (red.) (2013). Professionalization, Gender and Anonymity in the Global File Sharing Community. I Braga, R., \& Caruso, G. (red.), Piracy Effect. (s. 1-8). Cinergie.it.

Sundin, O., \& Haider, J. (2013). The networked life of professional encyclopaedias: quantification, tradition, and trustworthiness. First Monday, 18.

Sundholm, J. (2013). Stories of National and Transnational Memory: Renegotiating the Finnish Conception of Moral Witness and National Victimhood. I Finland's Holocaust : Silences of History. (s. 31-45). Palgrave Macmillan.

Sundholm, J. (2013). Finland at War on Screen since 1989: Affirmative Historiography ad Prosthetic Memory. I European Cultural Memory Post-89. (s. 209-239). Rodopi. 
Söderlund, P. (2013). Die skandinavischen Literaturgesellschaften: Finanzielle ind institutionelle Bedingungen für textkritische Ausgaben in Skandinavien. I Geschichte der Edition in Skandinavien. (s. 125-142). Walter de Gruyter.

Uldam, J., \& Askanius, T. (2013). Calling for Confrontational Action in Online Social Media: Video Activism as Auto-communication. I Cammaerts, B., Mattoni, A., \& McCurdy, P. (red.), Mediation and Protest Movements. Kapitel 8. (s. 159-178). Bristol: Intellect Ltd.

Vallinder, A., \& Olsson, E. J. (2013). Do computer simulations support the Argument from Disagreement? Synthese, 190(8), 1437-1454.

Wadstein MacLeod, K. (2013). Touched by Documenta 13. Konsthistorisk Tidskrift, 82(2), 115-117.
Wallander, K. (2013). Successful Images of Successful Ageing?: Representations of Vigorous Elderly People in a Swedish Educational Television Programme. Nordicom Review, 34(1/13), 91-103.

Winter, K., \& Bogren, A. (2013). The realization of sexed bodies: Stable and fragile gender dichotomies in Swedish media representations of biomedical alcohol research. Women's Studies : International Forum, 37, 53-63.

Wisselgren, P. (2013). "Not too many ladies, but too few gentlemen": On the gendered co-production of social science and its publics. I Social Science in Context: Historical, Sociological, and Global Perspectives. (s. 33-47). Nordic Academic Press. 


\section{New books from Nordicom}

\section{Freedom of Expression Revisited Citizenship and Journalism in the Digital Era}

Ulla Carlsson (red.) Göteborg: Nordicom, Göteborgs universitet, 2013. $171 \mathrm{~s}$. ISBN 978-91-86523-74-9.

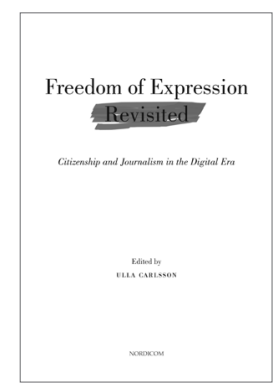

In recent years, there has been widespread concern about the ability of the media to maintain and develop their role as a pillar of democracy. Issues regarding freedom of expression, freedom of information and freedom of the press are more complex than ever. The Nordic region - Denmark, Finland, Iceland, Norway and Sweden - is among the most technology-intensive and "wired" regions in the world. These countries are similar in many respects, including their media systems. In the era of globalization, however, the Nordic countries are undergoing change on many fronts. From the point of view of welfare politics and democratic processes, these changes pose numerous challenges. The theme of this volume - Freedom of Expression Revisited. Citizenship and journalism in the digital era - could be summarized as critical perspectives on experiences and conceptions of freedom of expression and the media in contemporary communication societies. The book reflects Nordic as well as global perspectives. The contributors are leading Nordic scholars, but also professionals outside the Nordic region, who have been engaged for years in research on freedom of expression from different angels.

\section{A History of Swedish Broadcasting Communicative Ethos, Genres and Institutional Change}

Monika Djerf-Pierre \& Mats Ekström (eds) Göteborg, Nordicom; Stockholm, Stiftelsen Etermedierna i Sverige, 2013, 370 p., ISBN 978-91-86523-73-2.

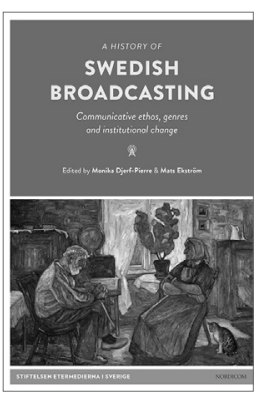

This book derives from a largescale research programme on Swedish broadcast history, which started in 1993. An impressive body of empirical studies has been published, covering a great variety of topics, genres and periods. With a few exceptions, this research has not previously been published for a non-Swedish reading audience.

The overall question explored in this book is how broadcast media have been developed as forms of public communication. The analyses focus on two basic and interrelated aspects of broadcast as public communica- tion. Firstly, the communication and social relationships created between broadcasters and audiences. The second aspect concerns broadcasting as social and cultural institutions.

\section{Towards a Better Internet for Children? Policy Pillars, Players and Paradoxes}

Brian O'Neill, Elisabeth Staksrud \& Sharon McLaughlin (eds) Göteborg, Nordicom;, 2013, 370 p., ISBN 978-91-86523-72-5.

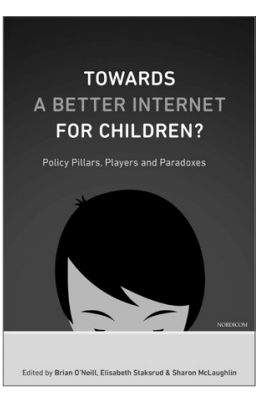

Keeping children safe online has been the subject of intensive policy debate ever since the mid-1990s when the internet first became an important public communications medium. The European Union has been to the fore in promoting internet safety and through its Safer Internet Programme has supported multi-stakeholder initiatives with industry, law enforcement, education and civil society to create a safer internet environment. Now, with a new emphasis on not just a safer but also a better internet, policy makers have signalled a new phase in strategies to protect children online. Reviewing the development of internet safety policy over this period - against the background of better evidence about the reality of young people's experiences - and looking to its future are among the key themes of this book. The contributors, all members of the now 33-country EU Kids Online network, seek to add to a growing literature on policy matters regarding internet regulation and governance as the Internet enters a new phase of maturity with near universal access and use. 